\title{
EFFECTS OF BAMBOO BIOCHAR AMENDMENT ON THE GROWTH AND PHYSIOLOGICAL CHARACTERISTICS OF FOKIENIA HODGINSII
}

\author{
TARIN, M. W. K. ${ }^{1}$ - FAN, L. ${ }^{1}$ - TAYYAB, M. ${ }^{2}-$ SARFRAZ, R. ${ }^{3}-$ CHEN, L. ${ }^{4}-$ HE, T. ${ }^{4}-$ RONG, J. ${ }^{1}-$ \\ CHEN, L. ${ }^{1}-$ ZHENG, Y. ${ }^{*}$ \\ ${ }^{1}$ College of Forestry, Fujian Agriculture and Forestry University \\ Fuzhou, Fujian 350002, P. R. China \\ ${ }^{2}$ College of Crop Science, Fujian Agriculture and Forestry University \\ Fuzhou, Fujian 350002, P. R. China
}

${ }^{3}$ Fujian Provincial Key Laboratory of Soil Environmental Health and Regulation, College of Resources and Environment, Fujian Agriculture and Forestry University, Fuzhou, P. R. China

${ }^{4}$ College of Arts \& College of Landscape Architecture, Fujian Agriculture and Forestry University, Fuzhou, Fujian 350002, P. R. China

*Corresponding author

e-mail: zys1960@163.com

(Received $30^{\text {th }}$ Aug 2018; accepted $1^{\text {st }}$ Nov 2018)

\begin{abstract}
Biochar (BC) as a soil amendment has become an encouraging practice due to its role in enhancing soil fertility and plant growth. Measurement of plant physiological attributes has been considered a necessary approach for the evaluation of this practice. Influence of $\mathrm{BC}$ on growth and physiological attributes of Fokienia hodginsii remains elusive. Therefore, the present study compares the efficacy of bamboo BC amendment at different levels on the growth and physiological attributes of $F$. hodginsii. BC was applied to soil with four different levels as Bo (Control), BB5 (5 g kg-1 of soil), BB20 (20 g kg-1 of soil) and BB80 (80 $\mathrm{g} \mathrm{kg}^{-1}$ of soil) and seasonal variation in chlorophyll pigments and photosynthetic rate were measured by constructing the light-response curve by using the modified model of rectangular hyperbola. Moreover, biochemical attributes, final biomass and soil physiochemical properties were also compared among seedlings treated with different $\mathrm{BC}$ levels. The results revealed that the addition of $\mathrm{BC}$ at higher dose significantly increased the chlorophyll pigments, photosynthetic rate and biochemical attributes compared to Bo. Moreover, compared to Bo, amendment of BB20 and BB80 in soil increased the morphological characteristics with a maximum increase of $29 \%$ in biomass with improved NPK dynamics. Overall, these findings support the idea that $\mathrm{BC}$ amendment into the soil can alleviate the physiological performance of these conifer seedlings by improving seedlings health with an appropriate supply of nutrients. Its addition in soil can be a promising tool for reforestation, but its impact on soil varies with $\mathrm{BC}$ feedstock and soil type.

Keywords: biochar amendment, biochemical attributes, chlorophyll pigments, photosynthesis, plant physiology, reforestation
\end{abstract}

Abbreviations: AK: Available Potassium, AN: Available Nitrogen, AP: Available Phosphorus, BB: Bamboo Biochar, BC: Biochar, Bo: Control/No Biochar, C: Carbon, CA: Chlorophyll A, Caro: Carotenoid, CB: Chlorophyll B, CI: Intercellular CO2 Concentration, Cond: Conductance to $\mathrm{H}_{2} \mathrm{O}$, CRD: Complete randomized design, EC: Electrical Conductivity, GHGs: Greenhouse Gasses, IUCN: International Union for Conservation of Nature, LCP: Light Compensation Point, LSP: Light Saturation Point, LUE: Light Use Efficiency, N: Nitrogen, OM: Organic Matter, P: Phosphorous, Pn: Photosynthetic Rate, Pn-Max: Maximum Photosynthetic Rate, PPFD: Photosynthetic Photon flux Density, PS: Photosynthetic, PSII: Photosystem II, Rd: Rate of dark respiration, TC: Total Chlorophyll, TN: Total Nitrogen, TP: Total Phosphorus, Trmmol: Transpiration Rate, TSP: Total Soluble Protein 


\section{Introduction}

Fokienia hodginsii (Dunn) A. Henry \& H. H. Thomas (Fujian cypress) is a monotypic taxon of the Cupressaceae family. Fokienia genus includes only one living species and one fossil species ( $F$. ravenscragensis). Being an olden and extensive species in southern China and Vietnam, it is currently listed as threatened worldwide throughout its distribution range (Luu and Thomas, 2000). Its timber has received great attention due to its use in artworks, construction and furniture. It has outstanding wood density; its timber is also being exported to Europe and elsewhere in Asia (Osborn, 2004). Currently, $F$. hodginsii is protected species (Criterion B2) in China and listed as vulnerable in the IUCN (International Union for Conservation of Nature) red list of threatened species (Ding et al., 2017; Thomas and Yang, 2013). IUCN and species survival commission (SSC) are responsible for elaborating the red list. Intensive over logging of this species has led to a severe reduction in its population (Nguyen et al., 2015). On the contrary, the rise in human population during last few decades has exerted enormous pressure on the natural ecosystem by increasing the urban area with developing roads and encroachment of agriculture into forest areas (Johnson et al., 1993; Tarin et al., 2017). Because of disturbance and destruction in habitat, rare species have become vulnerable and threatened to extinction (Hubbell, 2013). High rates of deforestation have resulted in many plants and animals species endangered and led to the local extinction (Dao and Hölscher, 2017; Sodhi et al., 2004). Furthermore, global temperature has raised approximately $0.85 \pm 0.20{ }^{\circ} \mathrm{C}$ during the last 130 years. It is estimated that constantly rising in temperature will lead towards harsh and unfavorable climatic conditions (e.g. drought, flood etc.) for plants (Alexander et al., 2006; Anderegg et al., 2015; Min et al., 2015).

Biochar (BC) is a carbon $(\mathrm{C})$ rich substance that is produced under an insufficient supply of oxygen by the pyrolysis of biomass. It is used as a soil amendment and its retention in soil has been recommended for mitigating climate change as it can not only sequester C but also increases plant yields (Ali et al., 2017; Tayyab et al., 2018). Additionally, it can improve the soil physiochemical, biological properties, and soil fertility which, in turn, increase in plant growth (Glaser et al., 2002; Tayyab et al., 2018). Certain considerations such as BC application method, frequency, properties, climatic conditions, and soil type are also main factors on which BC efficiency depends (Ameloot et al., 2013; Edenborn et al., 2015; Sarfraz et al., 2017). Due to its stability from degradation, BC has proved as a technology for mitigating greenhouse gases (GHG) emissions (Lehmann, 2007), hence it has potential to increase the size of the forest $C$ sink by enhancing forest output (Thomas and Gale, 2015). Moreover, BC also has significance in increasing nutrient uptake, modifies gas exchange characteristics, and photosynthesis in plants growing under water-deficit and nutrient-limited environments (Tayyab et al., 2018).

Furthermore, BC is a promising tool which recovers the degraded forest soils, reduces nutrients leaching losses, improves nutrients retention availability, and water holding capacity including soil structure (Amonette and Joseph, 2009). Alteration of soil nitrogen (N) dynamics can be the consequence of BC amendment (Clough et al., 2013; Clough and Condron, 2010) which can lead towards influence in soil available nitrogen (AN) including shift in biological N fixation (Rondon et al., 2007; Saarnio et al., 2013). Besides, few BCs include satisfactory nutrients and provide better results as a soil amendment (Hass et al., 2012; Uzoma et al., 2011). These BCs induced modifications in the soil which, in turn, alteration in leaf $\mathrm{N}$ status and other essential nutrients such as, 
phosphorous (P), (Vassilev et al., 2013) resulting affects the photosynthesis (Xu et al., 2015). Physiological attributes such as gas exchange, particularly photosynthetic rate (Pn) is the key feature, through the general performance and fitness of the plants can be considered. The synthesis of biochemical attributes (e.g. amino acids, total soluble proteins) is an environmentally organized factor where plants produce high amounts of amino acids under minimum stress conditions (Pant et al., 2011; Younis et al., 2015). Environmental stresses such as heat and cold during initial growing stages in climax species are the main reason for this failure. Plants may face photo inhibition, nutrient shortages, and drought during dry season. Light stress is common in tropical environments and photosynthetic pigment concentrations, especially carotenoid (Caro) are signs of plant sensitivity to light intensity (Vieira, 1996).

Recently, much more research work regarding the result of BC on soil physiochemical attributes and plant yield has been carried out on the agricultural and horticultural system. For example, Abiven et al. (2015) reported a significant rise in the maize branches under $\mathrm{BC}$ amendment where the effect of $\mathrm{BC}$ on plants cultivated under drought environments. Results from temperate forests have demonstrated that $\mathrm{BC}$ can positively influence tree growth by increasing nutrients and $\mathrm{C}$ stock including decreasing harmful effects (McElligott, 2011; Wardle et al., 1998). The physiological response of few forest species has been conducted by few researchers, for example seasonal variation in total soluble protein, 40 years old Oak seedlings by Manuel et al. (2004), in another study where seasonal variations in the photosynthetic capacity of Taiwan spruce (Picea morrisonicola Hay) was examined by Weng et al. (2005). Recently photosynthetic responses of evergreen broad-leaved tree species to ozone $\left(\mathrm{O}_{3}\right)$ were examined by Watanabe et al. (2018). It is necessary for better understanding in order to identify the parameters which are responsible for better growth and physiology. In the current experiment, we assumed that $\mathrm{BC}$ amendments at different doses may affect the plant physiological attributes (photosynthesis), biochemical composition, growth, and biomass of $F$. hodginsii. However, to the best of our knowledge, the present study is the first attempt in order to analyze the physiological response of $F$. hodginsii. The main goals of our experiment were (i) to document the information about this threatened species, because there is no scientific data regarding the growth pattern (ii) to distinguish the effect of different levels of BC amendment on physiological attributes of $F$. hodginsii; (iii) to identify the effect of $\mathrm{BC}$ amendments on soil properties and to know the growth pattern in term of seasonal variation in F. hodginsii.

\section{Materials and methods}

\section{Description of study area and design}

A pot experiment was carried out in Bamboo Institute of Fujian Agriculture and Forestry University (Fig. la, b), Fujian Province, China (lat. 26 ${ }^{\circ}{ }^{\prime} \mathrm{N}$, long. $119^{\circ} 13^{\prime} \mathrm{E}$, elevation $12 \mathrm{~m}$ ), where the average solar radiation per year is $1246 \mathrm{~kW} \mathrm{~h} \mathrm{~m}$. Commercial bamboo biochar (BB) produced at $450{ }^{\circ} \mathrm{C}$ was purchased from Nanjing Qinfeng Straw Technology Co. Ltd. and four different levels of BC were incorporated into soil as Bo (No Biochar/Control), BB5 (5 g kg-1 of soil), BB20 (20 g kg-1 of soil) and BB80 (80 $\mathrm{g} \mathrm{kg}^{-1}$ of soil). In March 2017, one-year-old seedlings of $F$. hodginsii were transplanted into pots and arranged in a completely randomized design (Fig. 1c) with four replications for each treatment with 32 plants in total (Wang et al., 2014). 


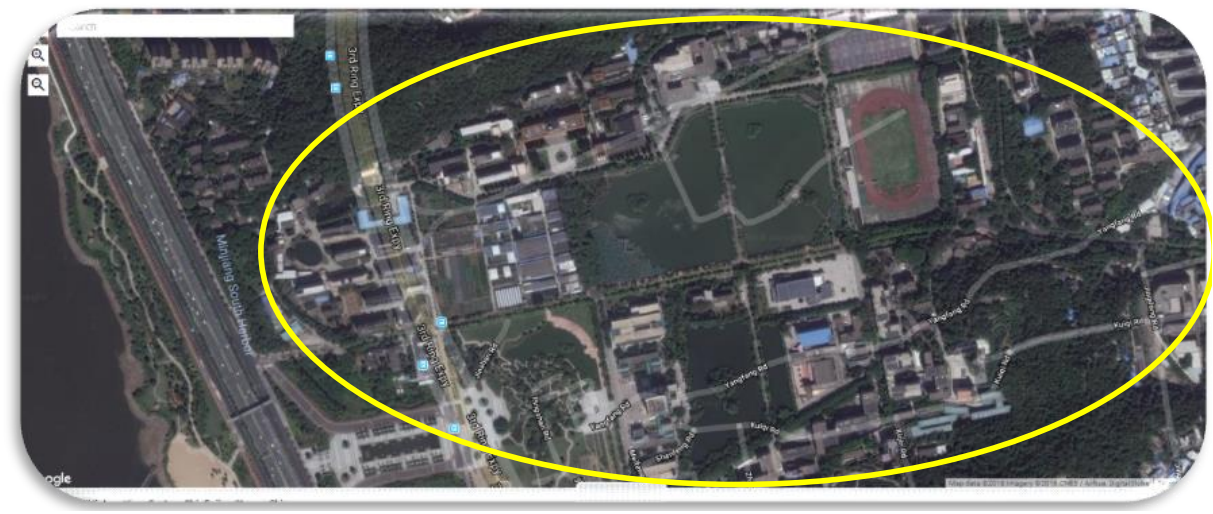

$\mathbf{a}$

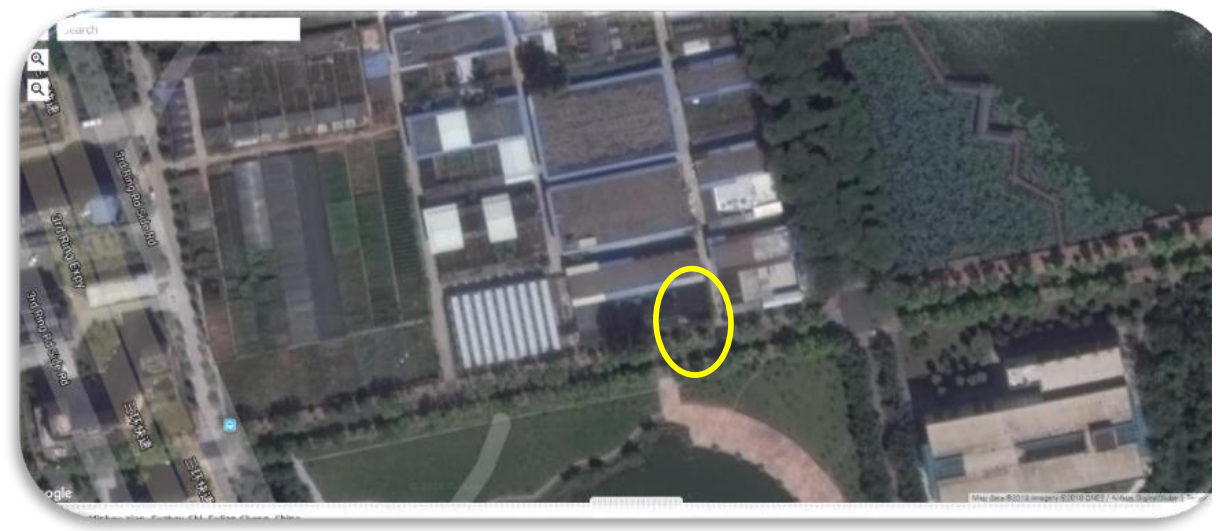

b

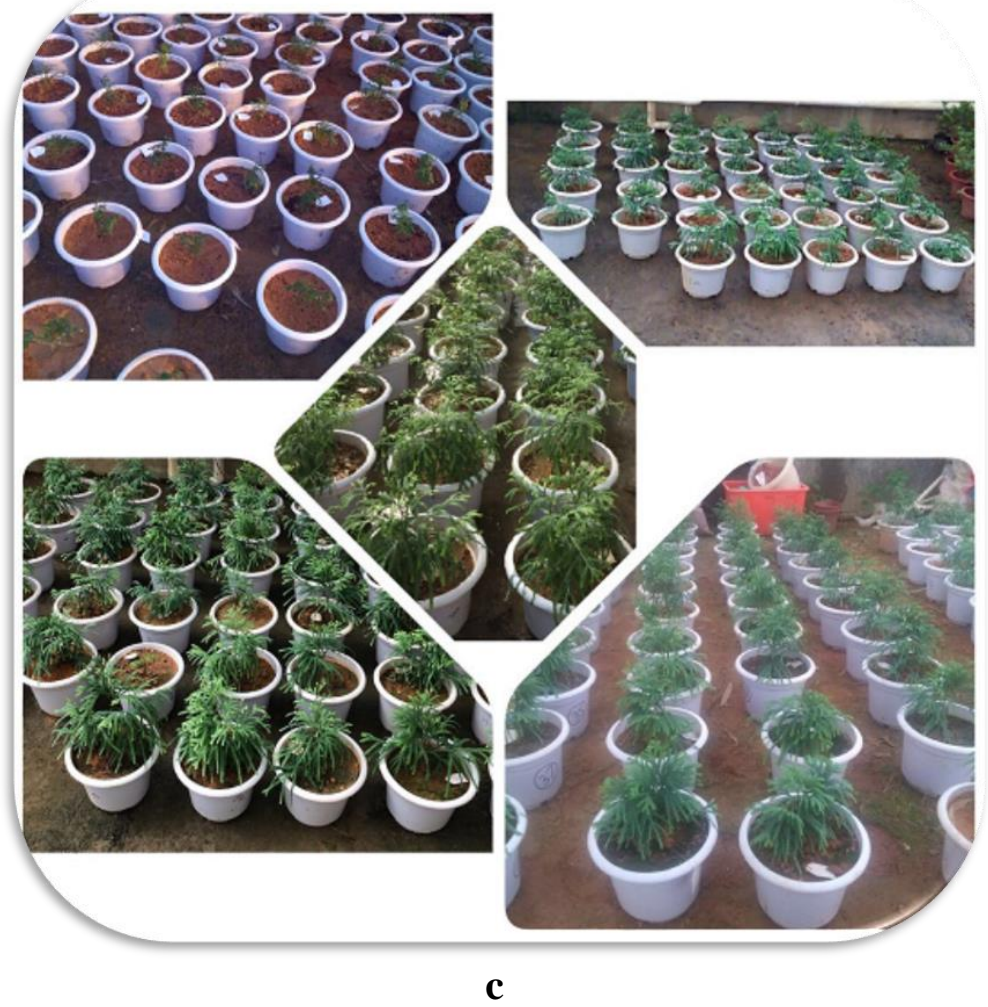

Figure 1. a. Boundary of Fujian Agriculture and Forestry University, Fuzhou Fujian Province China. $\boldsymbol{b}$ Bamboo Institute Fujian Agriculture and Forestry University. $\boldsymbol{c}$ Arrangements of pots in complete randomized design (CRD) treated with different levels of $B C$ amendments 
Plants were grown under the natural light condition and irrigated each pot depending upon the moisture level of the soil. All the seedlings (including control) were treated with NPK fertilizer (10 g each pot) after 15 days. After the interval of three months (June 2017), physiological attributes were measured. In addition, samples of leaf tissue were collected for further analysis for photosynthetic (PS) pigments like chlorophyll a (CA), chlorophyll b (CB), total chlorophyll (TC), carotenoids (Caro), and biochemical compositions (amino acid, ascorbic acid, soluble sugar and total soluble protein) and it was repeated till the end of March 2018 with the interval of three months.

\section{Physiochemical properties of soil and biochar}

The characteristics of Bamboo BC and soil were measured before its application by using standard protocols. In order to analyze physiochemical properties, soil samples were air-dried and then passed through a 2-mm mesh. By using glass electrode meter, soil $\mathrm{pH}$ (1:2.5 soil/water suspensions) was measured. Total nitrogen (TN) and soil total carbon (TC) were determined through the Elemental analyzer (Thermo Scientific ${ }^{\mathrm{TM}}$, Waltham, MA, USA). While total phosphorus (TP) and available phosphorus (AP) were determined by alkali fusion-Mo-Sb Anti-colorimetry method, extraction of available potassium (AK) was done through the application of ammonium acetate solution and then measured by a flame photometer (Pansu and Gautheyrou, 2007; Table 1).

Table 1. Physiochemical properties of soil and biochar used in this study

\begin{tabular}{c|c|c}
\hline Characteristics & Bamboo biochar & Soil \\
\hline $\mathrm{pH}$ & 9.687 & 4.685 \\
Electrical conductivity $\left(\mathrm{mScm}^{-1}\right)$ & 3.140 & 106.667 \\
Total nitrogen $\left(\mathrm{g}_{\mathrm{kg}} \mathrm{kg}^{-1}\right)$ & 6.243 & 0.497 \\
Total carbon $\left(\mathrm{g} \cdot \mathrm{kg}^{-1}\right)$ & 311.220 & 3.358 \\
Total phosphorous $\left(\mathrm{g} \cdot \mathrm{kg}^{-1}\right)$ & 0.399 & 0.256 \\
Available phosphorous $\left(\mathrm{mg}^{\mathrm{k}} \mathrm{kg}^{-1}\right)$ & 32.381 & 10.245 \\
Organic matter $\left(\mathrm{g} \cdot \mathrm{kg}^{-1}\right)$ & 536.543 & 5.790 \\
Available potassium $\left(\mathrm{g} \cdot \mathrm{kg}^{-1}\right)$ & 0.335 & 0.356 \\
C/N ratio & 49.975 & 6.864 \\
\hline
\end{tabular}

\section{Analyses of plant growth parameters}

After the interval of three months, leaves were collected from each treated seedling, washed extensively in distilled water, dried on filter paper, and either immediately used for analyses or frozen in liquid nitrogen and stored at $-80{ }^{\circ} \mathrm{C}$. At the end of the experiment (March 2018), Morphological parameters like, plant height $(\mathrm{cm})$ and diameter $(\mathrm{mm})$ were determined by measuring tape and Vernier calliper, respectively. For biomass and dry weight determination, uprooted seedlings were washed carefully, dried on filter paper and fresh weight was noted. Later these seedlings were tagged and oven-dried at $65^{\circ} \mathrm{C}$ for $48 \mathrm{~h}$ for dry weight. 


\section{Light-response curves of photosynthesis fitting}

From three different plant of each treatment, upper middle healthy and fully exposed leaves were measured for light-response curves. Measurements were carried out between 0900 and $1130 \mathrm{HR}$ from June 2017 to March 2018. Before each measurement $30 \mathrm{~min}$ photo-induction at $800 \mu \mathrm{mol} \cdot \mathrm{m}^{-2} \cdot \mathrm{s}^{-1}$ was essential. Photosynthetic photon flux density (PPFD) gradient of 2000, 1600, 1200, 1000, 800, $600,400,200,100,80,60,40,20,10$ and $0 \mu \mathrm{mol} \cdot \mathrm{m}^{-2} \mathrm{~s}^{-1}$ and $\mathrm{CO}_{2}$ concentration of $400 \mu \mathrm{mol}^{\mathrm{mol}}{ }^{-1}$ were used to measure the light-response curve using a portable photosynthesis system (LI-6400XT; LI-COR Biosciences, Lincoln, NE). The temperature of the chamber was $35 \pm 0.5 \mathrm{C}$ and the relative humidity was $50 \%$ to $70 \%$. At each PPFD, 3-5 min adaptation was required before taking the reading.

For a better understanding of photochemical yield relationship between PPFD and photosynthesis $(\mathrm{Pn})$, it is important to understand the light-response curve of Pn. There are numerous models for fitting the light-response curve of Pn such as "rectangular hyperbola model" (Thornley, 1976), "nonrectangular hyperbola model" (Thornley, 1976), and "modified model of rectangular hyperbola" (Ye, 2007). We used "modified model of rectangular hyperbola" with highly fitted data (approx. $\mathrm{R}^{2}>$ 0.99) for the light-response curves of Pn. The light-response curves of Pn were fitted following the modified model of rectangular hyperbola (Ye, 2007) as follows (Eq. 1):

$$
P n=\frac{(1-\beta P P F D)}{(1+Y P P F D)}(\alpha P P F D+R d)
$$

where Pn stands for net photosynthetic rate at the light (PPFD), Rd is the rate of dark respiration, and $\alpha$ is initial slope and also $\alpha, \beta$ and $\Upsilon$ are the coefficients which are independent of PPFD (Light). $\alpha$ also shows the increasing rate of Pn at very low PPFD.

Light use efficiency (LUE) can be calculated as follows (Chen et al., 2018b; Eq. 2):

$$
L U E=\alpha \frac{1-\beta P P F D}{1+Y P P F D}-\frac{R d}{P P F D}
$$

According to Equations 1 and 2, light use efficiency = Pn/PPFD can be calculated, so maximum light use efficiency is equal to $\alpha$. Hence $\alpha$ also indicate the maximum LUE of leaves at very low PPFD. Light compensation point (LCP), light saturation point (LSP) and maximum photosynthetic rate (Pn-Max) was calculated as follows (Ye et al., 2013; Eqs. 3-5):

$$
\begin{gathered}
L C P=-\frac{R d}{\alpha} \\
L S P=\frac{\sqrt{\frac{\beta+\gamma}{\beta}}}{Y}-1 \\
P n-\max =\alpha \frac{\sqrt{\beta+\gamma}-\sqrt{\beta}}{Y}-R d
\end{gathered}
$$




\section{Estimation of biochemical attributes and photosynthetic pigments}

Total soluble protein (wavelength: $595 \mathrm{~nm})$ and amino acids $(650 \mathrm{~nm})$ were determined following the procedures of (Brasford, 1976):

$$
\begin{gathered}
\text { Amino acids }(\mu \mathrm{g} / \mathrm{g})=\frac{\text { (Measure }- \text { Blank) }}{(\text { Standard }- \text { Blank })} * 50 \mu \frac{g}{m l} * \text { Soluble protein content } \\
\text { Total Soluble Protein }(\mathrm{g} / \mathrm{lit})=\frac{\text { (Measure }- \text { Blank) }}{\text { (Standard }- \text { Blank) }} * 0.563 \mathrm{~g} \text { Pro /lit }
\end{gathered}
$$

The concentration of ascorbic acid $(536 \mathrm{~nm})$ was determined using the formula of (Keller and Schwager, 1977) and soluble sugar absorbance at wavelength: $620 \mathrm{~nm}$ was determined with the anthrone reagent (Cakmak and Horst, 1991):

$$
\text { Ascorbic Acid }\left(\mu \frac{\mathrm{g}}{\mathrm{g}} \text { wet weight }\right)=\frac{\text { (Measure - Blank) }}{\text { (Standard - Blank) }} * 6 \mu \frac{g}{\mathrm{ml}} * 4 * \text { Soluble protein content }
$$

Soluble Sugar Content $(\mu \mathrm{g} / \mathrm{g}$ wet weight $)=$

$$
\begin{aligned}
& \frac{\text { (Measure }- \text { Blank })}{(\text { Standard - Blank) }} * 1000 \mu \mathrm{g} / \mathrm{ml} / \mathrm{sample} \text { weight } /(10 * \text { volume of distilled water }) \\
& \qquad \text { Multiple of sample Dilution }
\end{aligned}
$$

Photosynthetic (PS) pigment concentrations were calculated using equations for determination of chlorophylls a, b, total, and carotenoids by absorbance of extract at 663, 645 and $470 \mathrm{~nm}$ using the equations of (Lichtenthaler, 1987), and expressed as mg. $\mathrm{g}^{-1}$. PS pigments in the fresh leaves of the plant were extracted in $80 \%$ acetone for 48-72 $\mathrm{h}$ in darkness at $4{ }^{\circ} \mathrm{C}$ until the leaves color changed to white completely.

$$
\begin{aligned}
& \text { Chlorophyll A content }\left(\mathrm{mg}^{\circ} \mathrm{g}^{-1)}=(12.21 * \mathrm{D} 663-2.81 * \mathrm{D} 645 * \mathrm{~V} /(1000 * \mathrm{~W})\right. \\
& \text { Chlorophyll B content }\left(\mathrm{mg} \bullet \mathrm{g}^{-1}\right)=(20.13 * \mathrm{D} 645-5.03 * \mathrm{D} 663 * \mathrm{~V} /(1000 * \mathrm{~W}) \\
& \text { Total chlorophyll content }\left(\mathrm{mg} \cdot \mathrm{g}^{-1}\right)=(20.2 * \mathrm{D} 645+8.02 * \mathrm{D} 663 * \mathrm{~V} /(1000 * \mathrm{~W}) \\
& \text { Carotenoids }\left(\mathrm{mg} \bullet \mathrm{g}^{-1}\right)=(1000 * \mathrm{D} 470-3.27 * \mathrm{Ca}-104 * \mathrm{Cb}) / 229 * \mathrm{~V} /(1000 * \mathrm{~W}) \\
& \mathrm{Ca}=12.21 * \mathrm{D} 663-2.81 * \mathrm{D} 645 \\
& \mathrm{Cb}=20.13 * \mathrm{D} 645-5.03 * \mathrm{D} 663
\end{aligned}
$$

\section{Statistical analysis}

Statistical analysis was performed using SPSS-19 software and experimental data was expressed as means and standard errors. Differences in comparison of mean between different treatments were done by ANOVA and Duncan's multiple range tests at $\alpha 0.05$ probability level. Origin 8.5 and Microsoft excel was used for light response curves and graphs. 


\section{Results}

\section{Plant morphological features and plant biomass}

Plant morphological features such as plant height and basal diameter comparison are displayed in Figure 2a. Compared to Bo, seedlings treated with BB20 were taller while there was no significant difference in other treatments. Comparison of plant fresh weight under BB80, BB20 and BB5 amended soil showed 29\%, $8 \%$ and $6 \%$ higher respectively as compared to Bo. Similarly, compared to Bo, dry weight of the BC treated seedlings were increased by $16 \%, 14 \%$ and $7 \%$ under BB80, BB20 and BB5 amended soil, respectively (Fig. $2 b$ ).

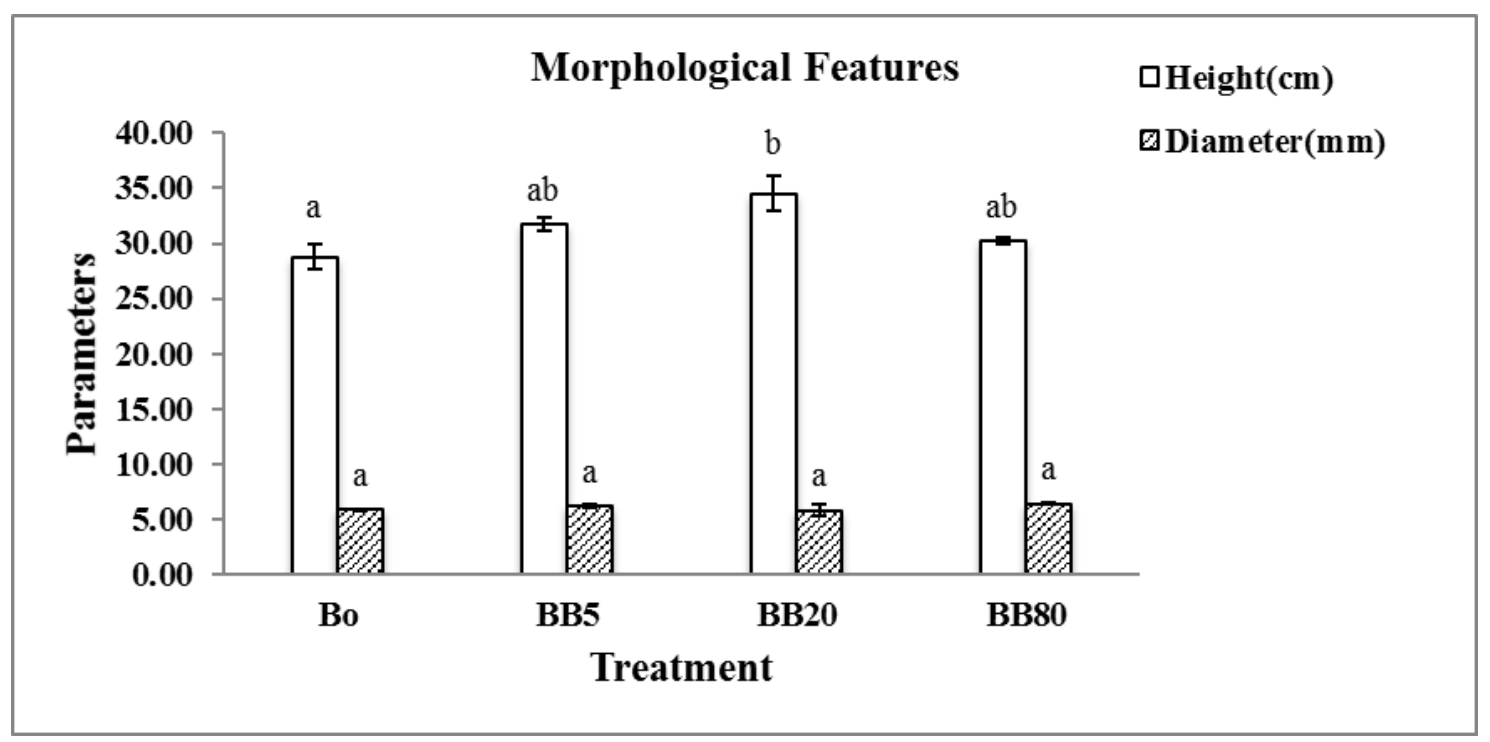

a

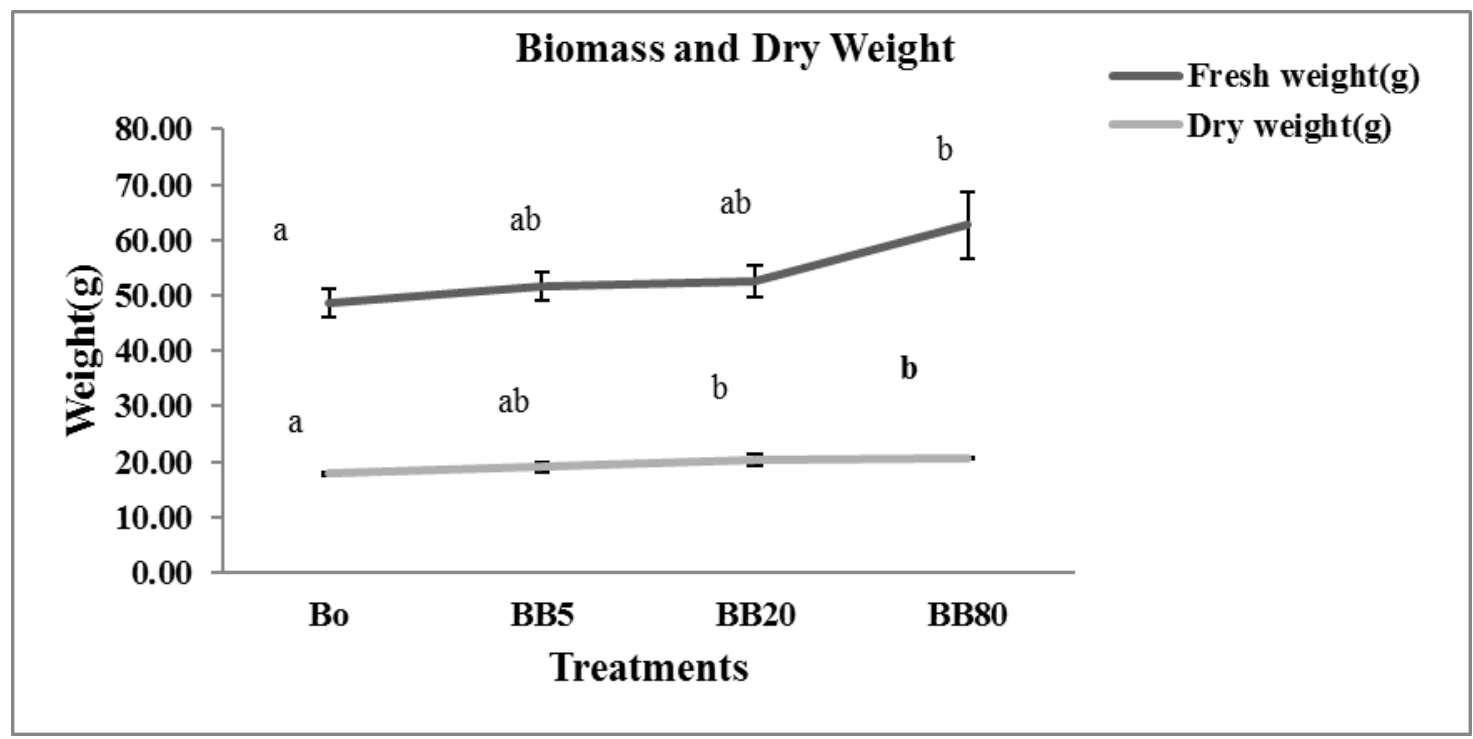

b

Figure 2. $\boldsymbol{a}$ Morphological parameters and $\boldsymbol{b}$ biomass and dry weight of seedlings treated with a different level of $B C$. The different letters on bars show significant differences $(P \leq 0.05)$ between BC application levels 


\section{Photosynthetic pigments concentrations}

The effect of Bamboo BC with various application rates $(0,5,20,80 \mathrm{~g} / \mathrm{kg})$ on PS pigments in four different seasons starting from June 2017 to March 2018 are depicted in Figure 3. The increase in PS pigments was observed by increasing the BC application rate BB20 and BB80. There was no significant difference in PS pigments in Bo and BB5 throughout the measurement period. When season wise PS pigments were compared, overall highest pigment concentrations were noted in June and September followed by lowest in December and March 2018, respectively (Fig. 3).

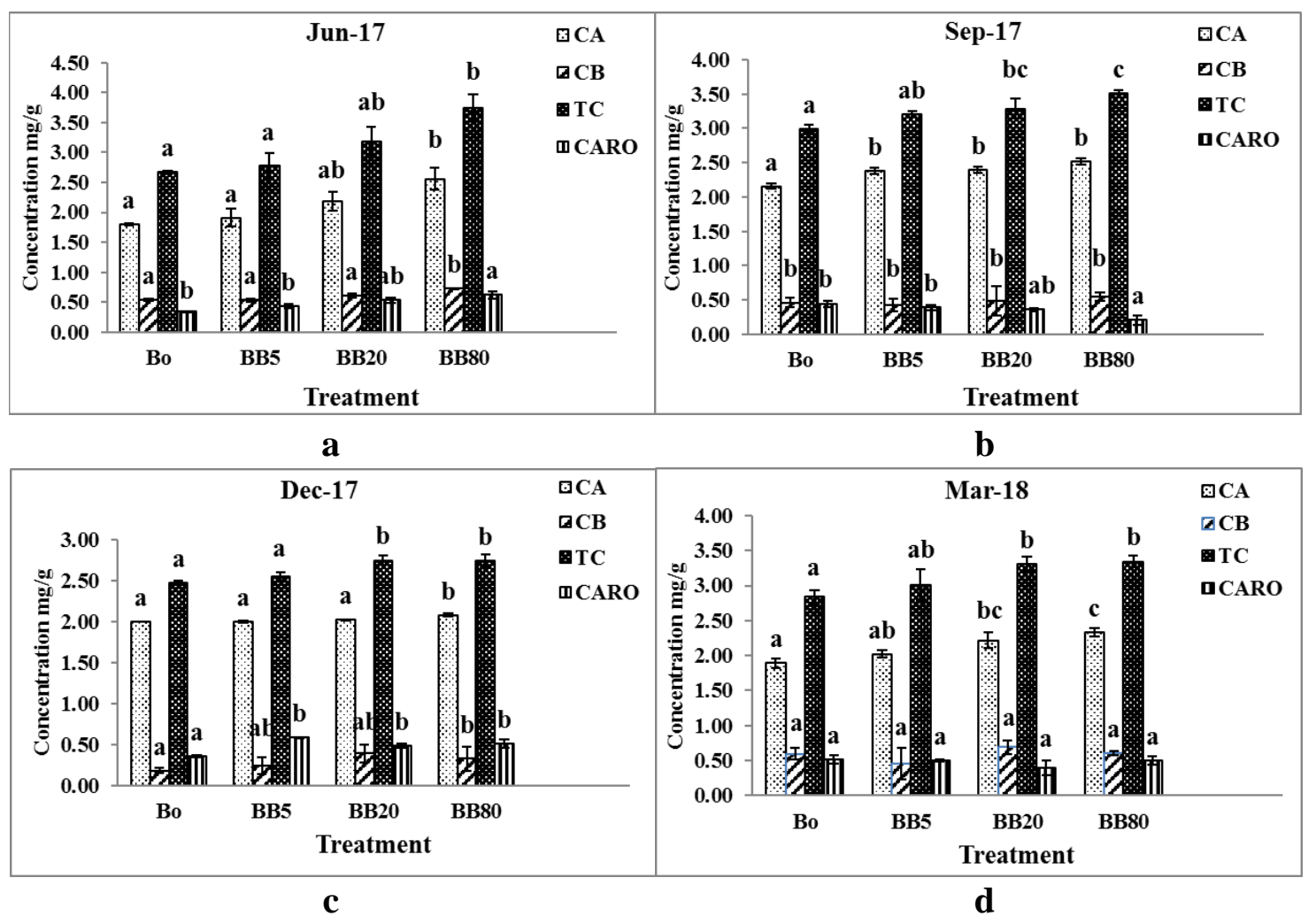

Figure 3. Seasonal contents of photosynthetic pigments. Chlorophyll a (CA), Chlorophyll b $(C B)$, Total Chlorophyll (TC), and CARO as carotenoid. The different letters on bars show significant differences $(P \leq 0.05)$ between $B C$ application levels

During first phase (June 2017), highest Chlorophyll a (CA) $2.56 \mathrm{mg} \cdot \mathrm{g}^{-1}$ concentrations were noted in BB80 followed by BB20, BB5 and Bo. Similar trend was observed in chlorophyll b (CB) concentrations. Total chlorophyll concentration (TC) in BB80 increased $40 \%$ over Bo and it was significantly different than Bo and BB5 (Fig. 3a). During second measurement period (September 2017), there was an overall increase in the PS pigment concentrations including Bo. There was significant difference in CA concertation between the plants treated with $\mathrm{BC}$ and Bo. TC concentration contributed highest in BB80 with an increase of $17 \%$ over Bo followed by $10 \%$ and $7 \%$ in BB20 and BB5 seedlings, respectively (Fig. 3b). During third measurement period (December 2017), there was a reduction in PS pigment concentration due to the decrease in temperature and daylight. There was no significant difference in CA concentration between Bo, BB5, and BB20 except BB80, where a significant difference was observed. 
As far as TC concentration is concerned, seedlings treated with BB80 and BB20 both showed highest (11\%) PS pigment concentration over Bo (Fig. 3c). In fourth phase (March 2018), there was certain rise in PS pigment concentration owing to rise in temperature. In CA concentration, there was no significant difference in Bo and BB5 treated seedlings but compared to Bo, a significant difference was observed in BB80 and BB20 treated seedlings. Compared to Bo, an increase of $18 \%, 17 \%$ and $6 \%$ was observed in TC concentration in BB80, BB20 and BB5, respectively (Fig. 3d)

\section{Biochemical attributes}

The concentrations of biochemical properties in the leaves tissue were significantly affected by the application of higher rates of BC. Complete seasonal comparisons of biochemical attributes under different BC amendments are shown in Table 2.

Table 2. Season wise biochemical attributes in seedlings treated with different levels of BC

\begin{tabular}{|c|c|c|c|c|}
\hline Treatment & Amino acid $\left(\mu g \cdot g^{-1}\right)$ & Ascorbic acid $\left(\mu g . g^{-1}\right)$ & Soluble sugar $\left(\mu \mathrm{g} \cdot \mathrm{g}^{-1}\right)$ & TSP (g.L $\left.{ }^{-1}\right)$ \\
\hline \multicolumn{5}{|c|}{ Jun-17 } \\
\hline Bo & $4.043 \mathrm{a}$ & $19.578 \mathrm{c}$ & $11040.974 a$ & $0.232 \mathrm{a}$ \\
\hline BB5 & $4.923 a$ & $14.814 \mathrm{c}$ & $11882.613 \mathrm{a}$ & $0.226 \mathrm{a}$ \\
\hline BB20 & $7.855 b$ & $11.977 \mathrm{ab}$ & $18361.018 b$ & $0.275 b$ \\
\hline BB80 & $8.546 b$ & $9.269 b$ & $24872.646 \mathrm{c}$ & $0.268 \mathrm{ab}$ \\
\hline \multicolumn{5}{|c|}{ Sep-17 } \\
\hline Bo & $0.999 a$ & $186.163 b$ & $24316.8 \mathrm{a}$ & $0.420 \mathrm{a}$ \\
\hline BB5 & $1.467 \mathrm{a}$ & $194.072 b$ & $24917.33 a$ & $0.530 \mathrm{ab}$ \\
\hline BB20 & $2.040 \mathrm{ab}$ & $128.392 \mathrm{ab}$ & $27223.67 \mathrm{ab}$ & $0.532 \mathrm{ab}$ \\
\hline BB80 & $2.658 \mathrm{~b}$ & $75.196 \mathrm{~A}$ & $31853.8 b$ & $0.637 \mathrm{c}$ \\
\hline \multicolumn{5}{|c|}{ Dec-17 } \\
\hline Bo & $1.445 \mathrm{a}$ & $76.845 \mathrm{~d}$ & $34623.276 \mathrm{a}$ & $0.159 \mathrm{~b}$ \\
\hline BB5 & $3.099 \mathrm{ab}$ & $47.854 \mathrm{c}$ & $37568.965 \mathrm{ab}$ & $0.181 \mathrm{~b}$ \\
\hline BB20 & $3.404 b$ & $23.660 \mathrm{~b}$ & $43666.379 b$ & $0.0865 \mathrm{a}$ \\
\hline BB80 & $3.758 b$ & $11.634 \mathrm{a}$ & $44137.931 b$ & $0.140 \mathrm{~b}$ \\
\hline \multicolumn{5}{|c|}{ Mar-18 } \\
\hline Bo & $1.323 \mathrm{a}$ & $37.748 \mathrm{c}$ & $36000.000 \mathrm{a}$ & $0.169 \mathrm{a}$ \\
\hline BB5 & $1.722 \mathrm{a}$ & $19.424 b$ & $41086.206 b$ & $0.191 \mathrm{a}$ \\
\hline BB20 & $1.951 \mathrm{a}$ & $19.062 b$ & $41155.172 b$ & $0.153 \mathrm{a}$ \\
\hline BB80 & $2.455 \mathrm{a}$ & $5.928 \mathrm{a}$ & $41681.034 b$ & $0.180 \mathrm{a}$ \\
\hline
\end{tabular}

Different letters indicate significant difference at $p<0.05$

Highest concentrations of total amino acid were observed in June 2017. Overall there was no significant difference in total amino acid concentration in Bo and BB5, lowest amino acid concentrations in Bo were noted in September 2017 rather than BC treated seedlings (Table 2). Compared to Bo, lower ascorbic acid concentrations were noted in all the treatments during entire experimental periods, overall higher concentrations were noted in September 2017, but concentrations of ascorbic acid were decreased by increasing the level of BC (Table 2). Comparatively, soluble sugar concentrations were highest in December 2017. Overall, a higher dose of BC application increased the 
concentrations of soluble sugar throughout the measurement period. Total soluble protein (TSP) concentrations were highest in September 2017 followed by June 2017, March 2018 and December 2017, respectively. In March 2018, there was no significant difference in TSP concentration but overall higher concentrations were noted with increased $\mathrm{BC}$ application rate (Table 2).

\section{Gas exchange attributes and light-response curves of photosynthesis}

The chlorophyll concentration has a significant role in plant as it directly affects the photosynthesis. The modified rectangular hyperbola values came close $\left(\mathrm{R}^{2}\right)$ with the measured values for all the treatments throughout the experiment period in all seasons. Seasonal comparison in term of photosynthetic parameters is presented in Table 3 .

Table 3. Season wise photosynthetic parameters include: initial slope ( $\alpha$ ), maximum photosynthetic rate (Pn-max), light saturation point (LSP), light compensation point (LCP), rate of dark respiration $(R d)$ and adjusted $R^{2}$ showing calculated and measured values are presented to show the degree of fit between the calculated and measured values

\begin{tabular}{|c|c|c|c|c|c|c|}
\hline Treatment & $\begin{array}{c}\alpha \\
\mu m o l . m^{-2} \cdot s^{-1}\end{array}$ & $\begin{array}{c}\text { Pn-Max } \\
{\left[\text { CO2 }\left(\mu \mathrm{mol} . \mathrm{m}^{-2} \cdot \mathrm{s}^{-1}\right)\right]}\end{array}$ & $\begin{array}{c}\text { LSP } \\
\mu \mathrm{mol} . \mathrm{m}^{-2} \cdot \mathrm{s}^{-1}\end{array}$ & $\begin{array}{c}\text { LCP } \\
\mu \mathrm{mol} . \mathrm{m}^{-2} \cdot \mathrm{s}^{-1}\end{array}$ & $\begin{array}{c}\text { Rd } \\
{\left[\mathrm{CO2}\left(\mu \mathrm{mol} . \mathrm{m}^{-2} \cdot \mathrm{s}^{-1}\right)\right]}\end{array}$ & $\mathbf{R}^{2}$ \\
\hline \multicolumn{7}{|c|}{ Jun-17 } \\
\hline Bo & $0.062 \mathrm{a}$ & $3.482 \mathrm{a}$ & $745.170 a$ & $16.013 \mathrm{a}$ & $0.817 \mathrm{a}$ & $0.992 \mathrm{a}$ \\
\hline BB5 & $0.079 a$ & $4.101 \mathrm{a}$ & $738.025 \mathrm{a}$ & $11.415 \mathrm{a}$ & $0.874 \mathrm{a}$ & $0.995 \mathrm{a}$ \\
\hline B20 & $0.086 a$ & $5.960 \mathrm{~b}$ & $982.550 \mathrm{a}$ & $11.939 a$ & $1.046 \mathrm{a}$ & $0.993 a$ \\
\hline B80 & $0.084 a$ & $6.667 b$ & $888.619 a$ & $12.318 \mathrm{a}$ & $0.932 \mathrm{a}$ & $0.992 \mathrm{a}$ \\
\hline \multicolumn{7}{|c|}{ Sep-17 } \\
\hline Bo & $0.085 a$ & $5.127 \mathrm{a}$ & $729.300 a$ & $5.461 a$ & $0.474 a$ & $0.996 \mathrm{a}$ \\
\hline BB5 & $0.099 a$ & $5.294 a$ & $988.741 \mathrm{a}$ & $4.618 \mathrm{a}$ & $0.475 a$ & $0.997 \mathrm{a}$ \\
\hline BB20 & $0.088 \mathrm{a}$ & $6.917 b$ & $1045.239 a$ & $4.461 \mathrm{a}$ & $0.398 \mathrm{a}$ & $0.996 a$ \\
\hline BB80 & $0.104 \mathrm{a}$ & $7.528 \mathrm{~b}$ & $1076.567 \mathrm{a}$ & $4.233 \mathrm{a}$ & $0.439 \mathrm{a}$ & $0.998 \mathrm{a}$ \\
\hline \multicolumn{7}{|c|}{ Dec-17 } \\
\hline Bo & $0.062 \mathrm{a}$ & $3.010 \mathrm{a}$ & $733.430 a$ & $15.053 \mathrm{c}$ & $0.930 \mathrm{a}$ & $0.990 a$ \\
\hline BB5 & $0.064 \mathrm{a}$ & $3.089 \mathrm{a}$ & $735.953 a$ & $13.941 \mathrm{c}$ & $0.885 a$ & $0.991 \mathrm{a}$ \\
\hline BB20 & $0.067 \mathrm{a}$ & $3.556 a$ & $914.154 \mathrm{a}$ & $10.115 b$ & $0.702 \mathrm{a}$ & $0.996 \mathrm{a}$ \\
\hline BB80 & $0.077 \mathrm{a}$ & $3.929 a$ & $906.378 \mathrm{a}$ & $8.112 \mathrm{a}$ & $0.636 a$ & $0.991 \mathrm{a}$ \\
\hline \multicolumn{7}{|c|}{ Mar-18 } \\
\hline Bo & $0.080 \mathrm{a}$ & $3.948 \mathrm{a}$ & $711.9354 a$ & $14.332 b$ & $0.941 \mathrm{c}$ & $0.997 \mathrm{a}$ \\
\hline BB5 & $0.103 b$ & $4.422 \mathrm{ab}$ & $737.369 a$ & $8.202 \mathrm{a}$ & $0.730 \mathrm{bc}$ & $0.992 \mathrm{a}$ \\
\hline BB20 & $0.092 \mathrm{ab}$ & $5.050 \mathrm{~b}$ & $790.329 a$ & $5.319 a$ & $0.466 \mathrm{ab}$ & $0.997 \mathrm{a}$ \\
\hline BB80 & $0.086 \mathrm{ab}$ & $5.128 \mathrm{~b}$ & $834.180 \mathrm{a}$ & $4.757 \mathrm{a}$ & $0.384 a$ & $0.991 \mathrm{a}$ \\
\hline
\end{tabular}

Different letters indicate significant difference at $p<0.05$

The overall net Pn increased at higher dose of BC through producing higher PS pigments. The comparison of light-response curves between all the seasons including all the treatment combination is presented in Figure 4. Although seedlings treated with higher dose of $\mathrm{BC}$; $\mathrm{BB} 20$ and $\mathrm{BB} 80$ responded maximum photosynthetic rates (Pn$\max )$. The increase in Pn-max for the month of June and September were recorded followed by relatively lower Pn-Max in March and December, respectively, while there was no significant difference in Pn-max in seedling treated with BB5 or Bo. Pn increased with increase in PPFD and reached LSP while with further increase in PPFD, Pn decreased because of photo-inhibition, according to modified model of rectangular hyperbola Pn-max and LSP were decreased whereas LCP was increased. Besides the data recorded from LiCor-6400 XT used for light-response curve for photosynthetic parameters at different PPFD (light points), Conductance to $\mathrm{H}_{2} \mathrm{O}$ (Cond), Intercellular $\mathrm{CO}_{2}$ Concentration $(\mathrm{CI})$ and Transpiration rate (Trmmol) were also recorded at different 
PPFD, where high Cond and Trmmol were noted in September 2017 at high PPFD with increased Pn and decreased CI. Season-wise plots for Cond, CI and Trmmol are shown in Figures 5, 6 and 7, respectively, with different BC amendments.

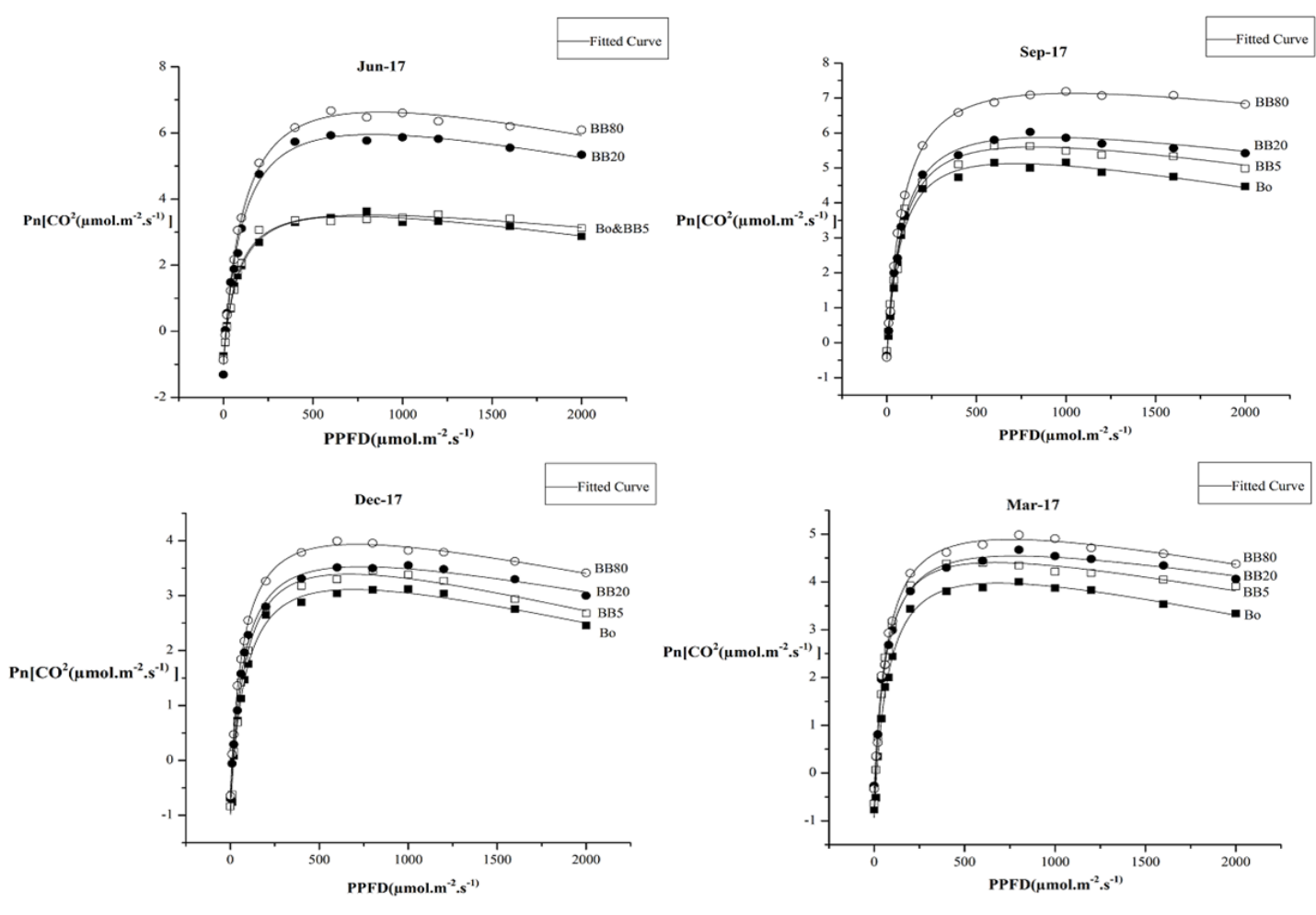

Figure 4. Response of net photosynthetic rate (Pn) of different photosynthetic photon flux density levels (PPFD) in different BC level

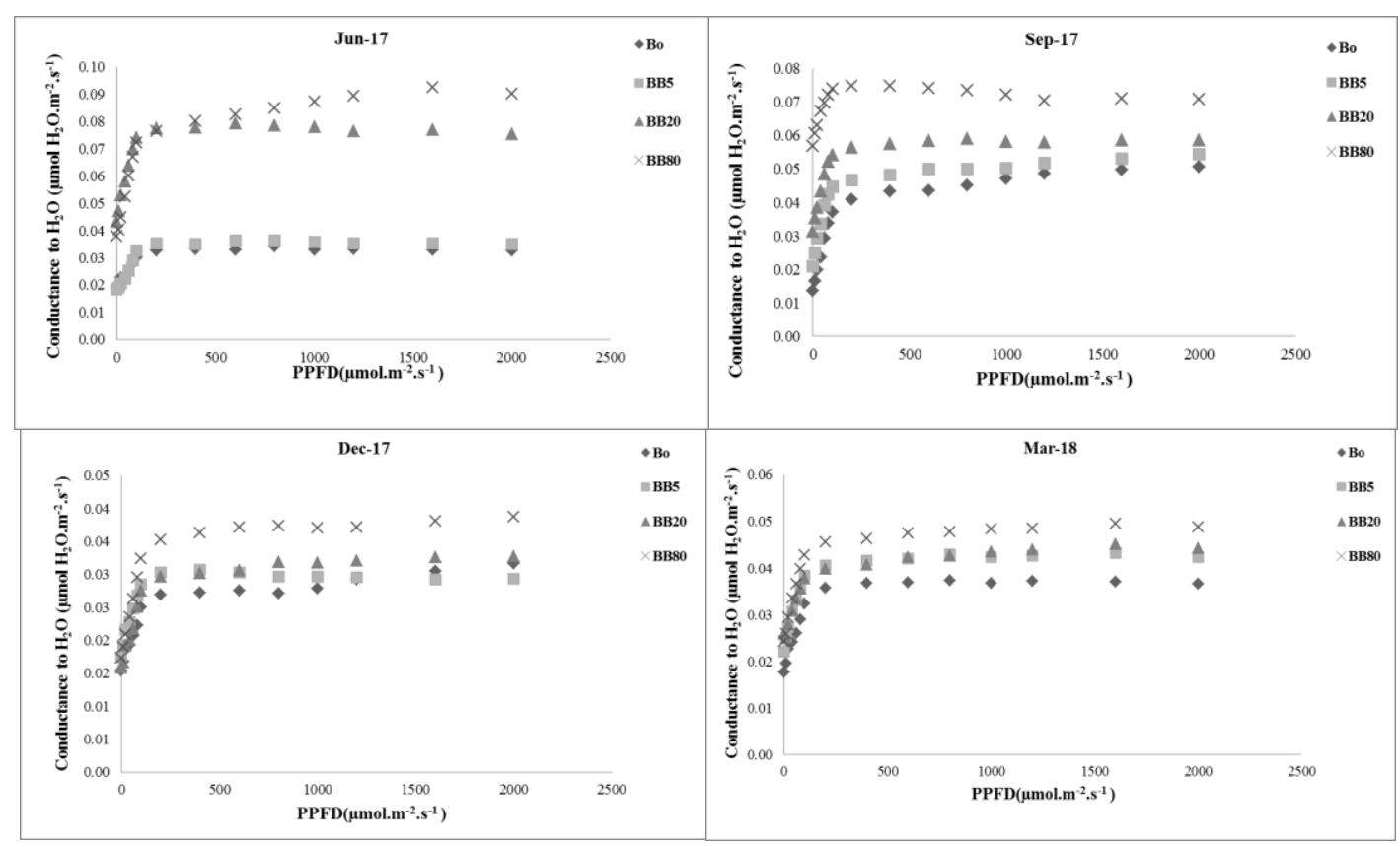

Figure 5. Seasonal comparison conductance to $\mathrm{H}_{2} \mathrm{O}\left(\mu \mathrm{mol} \mathrm{H}_{2} \mathrm{O} \cdot \mathrm{m}^{-2} \cdot \mathrm{s}^{-1}\right)$ in seedling treated different $B C$ level 


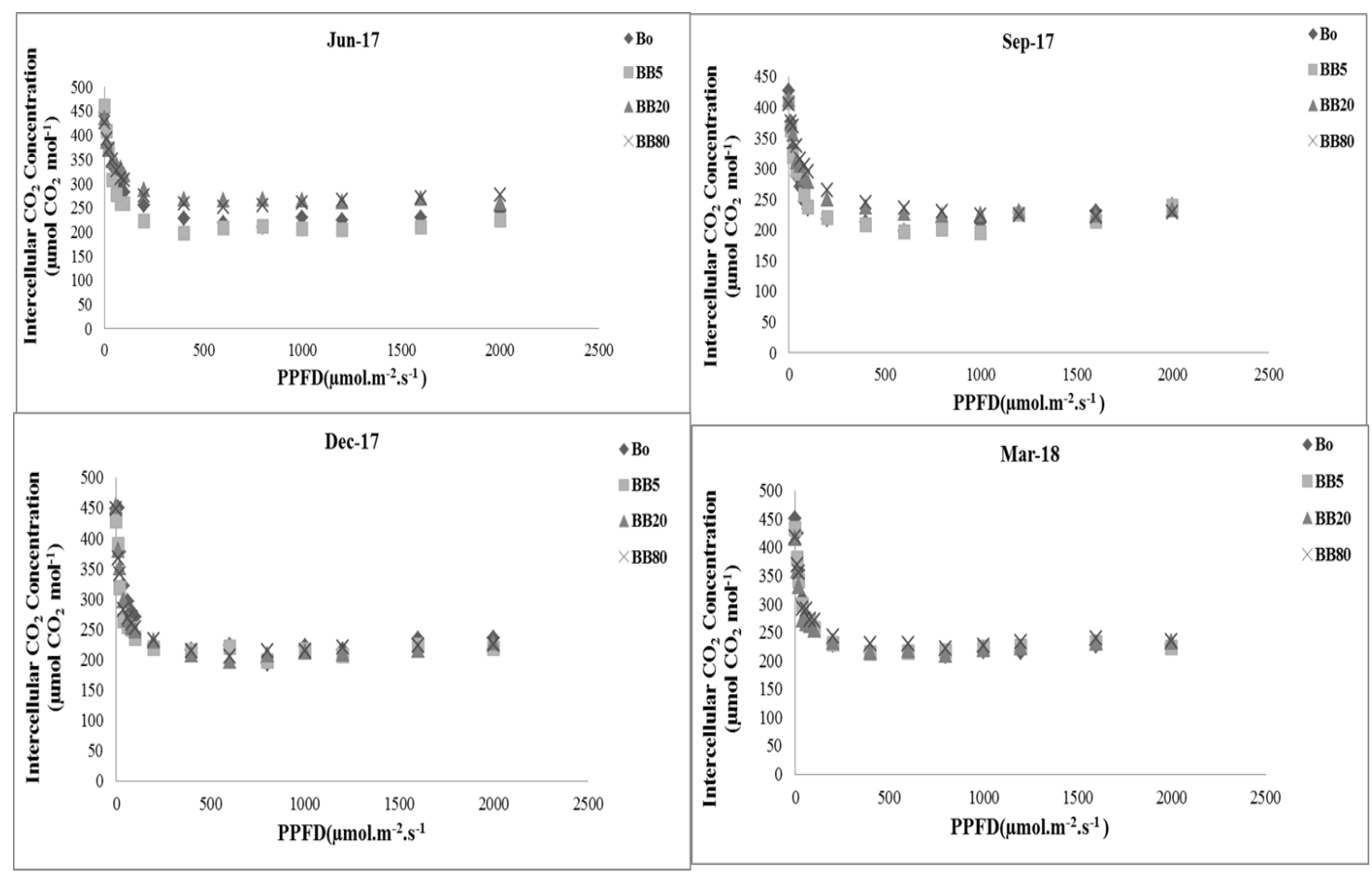

Figure 6. Seasonal comparison in intercellular $\mathrm{CO}_{2}$ concentration $\left(\mu \mathrm{mol} \mathrm{CO}_{2} \mathrm{~mol}^{-1}\right)$ in seedling treated with different $B C$ level

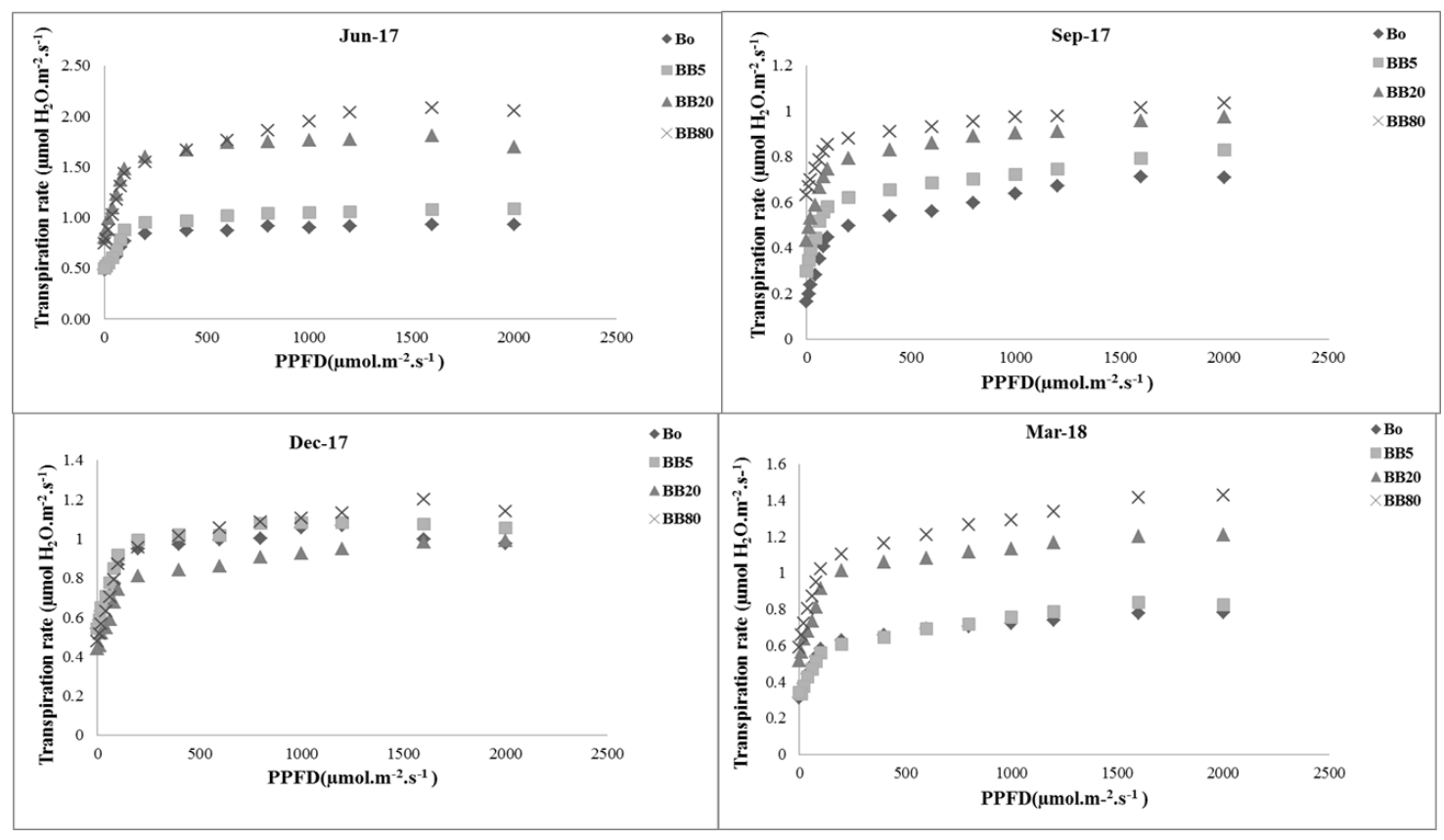

Figure 7. Seasonal comparison in transpiration rate $\left(\mu \mathrm{mol} \mathrm{H}_{2} \mathrm{O} . \mathrm{m}^{-2} . \mathrm{s}^{-1}\right)$ in seedling treated with different $B C$ level

\section{Influence of BC on soil properties}

Physiochemical properties of $\mathrm{BC}$ amended soils at the end of experiment are shown in Table 4. After one-year experiment, soil nutrient dynamics were notably changed. 
Compared to Bo all other BC treated soil presented higher macronutrients (NPK), soil TC and organic matter for the better growth and physiological parameters of seedlings. $\mathrm{TP}$, soil TC, AP and TN showed significantly higher values than pots without $\mathrm{BC}$ amendments.

Table 4. Chemical properties of soil treated with different levels of BC amendments

\begin{tabular}{c|c|c|c|c|c|c|c}
\hline & $\begin{array}{c}\mathbf{T N} \\
(\mathbf{g . k g}\end{array}$ & $\begin{array}{c}\mathbf{T P} \\
\left(\mathbf{g . k g}^{-\mathbf{1}}\right)\end{array}$ & $\begin{array}{c}\mathbf{A P} \\
(\mathbf{m g . k g}\end{array}$ & $\begin{array}{c}\mathbf{A K} \\
\left(\mathbf{g . k g}^{-\mathbf{1}}\right)\end{array}$ & $\begin{array}{c}\mathbf{O M} \\
\left(\mathbf{g . k g}^{-\mathbf{1}}\right)\end{array}$ & $\begin{array}{c}\text { Soil TC } \\
\left(\mathbf{g . k g}^{-1}\right)\end{array}$ & $\mathbf{C : N}$ \\
\hline Bo & $0.488 \mathrm{a}$ & $0.283 \mathrm{a}$ & $8.609 \mathrm{a}$ & $0.294 \mathrm{a}$ & $6.875 \mathrm{a}$ & $3.988 \mathrm{a}$ & $8.172 \mathrm{a}$ \\
BB5 & $0.506 \mathrm{~b}$ & $0.298 \mathrm{a}$ & $9.246 \mathrm{~b}$ & $0.341 \mathrm{a}$ & $12.378 \mathrm{~b}$ & $7.180 \mathrm{~b}$ & $14.204 \mathrm{~b}$ \\
BB20 & $0.548 \mathrm{c}$ & $0.312 \mathrm{a}$ & $9.297 \mathrm{~b}$ & $0.389 \mathrm{a}$ & $18.139 \mathrm{c}$ & $10.522 \mathrm{c}$ & $19.208 \mathrm{c}$ \\
BB80 & $0.587 \mathrm{~d}$ & $0.452 \mathrm{~b}$ & $9.718 \mathrm{c}$ & $0.835 \mathrm{~b}$ & $36.841 \mathrm{~d}$ & $21.369 \mathrm{~d}$ & $36.404 \mathrm{~d}$ \\
\hline
\end{tabular}

Different letters indicate significant difference at $p<0.05$

\section{Discussion}

\section{Morphological features and growth}

Results of this study showed that the growth of $F$. hodginsii seedlings was significantly improved under BC amendment rather than Bo (Fig. 2a, b). A great deal of studies has demonstrated the $\mathrm{BC}$ input to soil has great promise in improving plant growth and yield with application less than 1 to over $100 \mathrm{t} \mathrm{ha}^{-1}$ (Graber et al., 2010; Major et al., 2010; Wang et al., 2014). In our study, the application rate of $5 \mathrm{~g} \mathrm{~kg}^{-1}$ BC is correspondent to an application of $10.1 \mathrm{t} \mathrm{ha}^{-1}$ if planned for the plough layer of about $0.15 \mathrm{~m}$ with an average bulk density of $1.35 \mathrm{~g} \mathrm{~cm}^{-3}$. The application of BC to soil has increased the plant height and fresh weight of F. hodginsii seedlings (Fig. 2a, b), which is consistent with previous findings (Elmer and Pignatello, 2011). BC has the potential to provide essential nutrient with better water holding capacity because of its structure, as predicted by few workers in previous studies that $\mathrm{BC}$ increases the ion uptake with improved water holding capacity, resulting in increased water consumption ability by the plants (Uzoma et al., 2011; Younis et al., 2015).

\section{Seasonal variation in photosynthetic pigments concentrations and gas exchange with photosynthetic parameters}

The results depicted in Figure 3 indicate that except Bo and BB5 higher values of PS pigments were noted in BB20 and BB80 transplanted seedling. Thus more production of PS pigments was noted in $F$. hodginsii seedlings treated with higher doses of $\mathrm{BC}$. The rise in atmospheric temperature and $\mathrm{CO}_{2}$ concentration with adequate water supply are projected to increase the light-response of Pn. Cond, CI, and Trmmol were also recorded at 15 different PPFD. In all treatment combinations, Pn, Cond, and Trmmol increased up to some extent with increasing the intensity of PPFD and then decrease; while CI increased at low PPFD. A significant increase in PS pigments and Pn especially, in seedlings treated with BB20 and BB80 was observed in our experiment which is an agreement to previous results (Danish et al., 2014; Wang et al., 2014; Younis et al., 2015). There was no significant difference in LSP, LCP and Rd as presented in Table 3. BC promoted the PS pigments concentrations (Fig. 3a, b) resulted in maximum Pn during June 2017 and September 2017, as shown in Figure 4 because BC not only improves the availability of nutrients but also stimulates the growth by improving the photosynthetic pigments productions (Lehmann et al., 2006). Increase in 
PS pigments such as $\mathrm{CA}$ and $\mathrm{TC}$ in all the $\mathrm{BC}$ treated seedlings resulted in maximum PS rates because Pn is dependent on the concentration of PS pigments (Chen et al., 2018a). Moreover, in June and September, the temperature was feasible for the growth and development of the conifers besides growing season of this conifer; $F$. hodginsii is from July- September, where overall higher PS pigments concentrations resulted in maximum Pn. The lowest PS pigments were noted in all treatments in winter (December 2017) but seedlings treated with BC showed relatively higher Pn compared to Bo. In March 2018, BC treated seedlings showed higher PS pigments concentrations compared to December 2017 (Fig. 3d). Presumably, Fokienia hodginsii retains some Pn capacity in winter and regains in spring and summer when the temperature increases. Similar results were also found in other studies, where the PS pigments of conifers vary with environmental temperature (Colom et al., 2003; Richardson et al., 2001; Weng et al., 2005).

\section{BC effect on soil properties and biochemical attributes}

The physiochemical properties of the soil at the end of experiment were improved (Table 4), which is consistent with previous findings (Altland and Locke, 2013; Liang et al., 2006). Cheng et al. (2008) suggested that when BC-added in the soil resulting surface oxidation by biotic and abiotic agents establishing negative charges that give capability to BC to sorb more nutrients. Later these essential nutrients can be utilized by plants with ease. Higher concentration of amino acid in June 2017 was because of availability of essential nutrients especially nitrogen, because NPK fertilizer was applied during the first phase of the experiment, assuming more uptake of nutrients. Previous studies on BC have suggested that efficiency of BC increases when combined with fertilizer. As predicted by Huang et al. (2014) that addition of BC might be more effective when applied together with fertilizer, with more uptake of nitrogen with more growth (Alburquerque et al., 2013). BC treated seedlings showed highest TSP concentrations in September 2017 because the growing season of this conifer is July to September and biochemical variation is responsive to availability of resources which vary season to season containing higher values during the growing season and lower values during cold winter months (Matson et al., 1994; Billow et al., 1994). Moreover, synthesis of protein and amino acid are environmentally controlled factor, under minimum or zero stress conditions plants produce high amounts of amino acids (Pant et al., 2011; Younis et al., 2015). Compared to Bo, low ascorbic acid concentrations were noted in BC treated pots throughout the experiment period because ascorbic acid is an antioxidants molecules and increased levels of ascorbic acid concentration in Bo treated seedlings is defense mechanisms against oxidative or abiotic stress, especially in summers when the temperature is high. Plants exposed to environmental stress could accumulate higher amounts of anti-oxidants; our results showed that $\mathrm{BC}$ amendment is useful to improve plant antioxidant ability led to reducing the concentrations of ascorbic acids in BC treated seedlings as predicted by Wang et al. (2014). The season wise concentrations of soluble sugars (Table 2) in BC treated seedlings were lower in summer and higher in winter. Role of sugars in the growth and development of the plants is significant which is also supported by the previous findings (Wang et al., 2014; Younis et al., 2015). Where water deficit or polluted soils treated with BC have shown higher concentrations of soluble sugars in control pots, which is contradictory to our findings, $\mathrm{BC}$ treated pots showed higher concentrations of soluble sugars. On the basis of molecular, biochemical and genetic experiments it has been concluded that soluble 
sugars play a key role in control of plant metabolism, development and growth (Yuanyuan et al., 2010). Furthermore, it has been reported by Yuanyuan et al. (2010) and Siminovitch (1981). Additionally, the plant's soluble sugar concentration increases during the winter subjected to low temperature conversely decrease in high temperature. Higher concentration of soluble sugars with decreased temperature in winter enables plant to survive against freezing stress (Shao et al., 2008).

\section{Conclusion}

Although the addition of BC as an organic input in degraded soils has been viewed as a highly encouraging management practice to augment soil fertility and productivity. The study was to inspect under which BC concentration $\left(0,5,20,80 \mathrm{~g} \mathrm{~kg}^{-1}\right.$ of soil), soil quality and growth/biomass of $F$. hodginsii seedling will be improved. Our present research contributes toward understanding the influence of $\mathrm{BC}$ amendment on soil fertility and productivity, with a focus on the response of growth and physiological attributes of the $F$. hodginsii. Overall, compared to Bo, seedlings treated with BB80 responded positively, with an average increase of $28 \%$ in biomass, alleviation of other parameters such as PS pigment concentration, and Pn, which supports our hypothesis that $\mathrm{BC}$ addition may positively affect the growth and physiological features of the plant. The seasonal variation in plants treated with different levels of $\mathrm{BC}$ amendments responded differently in different seasons where higher photosynthetic rates were monitored in growing seasons and reversely in winter. Moreover, improvement in soil physiochemical properties is attributed to $\mathrm{BC}$ input in this experiment. Amendment of BC improves the early growth of Fokienia hodginsii seedlings suggesting a valuable tool for reforestation, especially when the species is endangered or threatened. But it is unclear that same kind of response will be attained if $\mathrm{BC}$ will be applied to older trees with much slower growth rates. Moreover, BC impact on soil varies with BC feedstock and soil type. Further works should be carried out to identify the effects of BC amendments on below ground like root morphological features and the soil microbial community. Additionally, for mitigation of global warming, studies about greenhouse gasses emission should be conducted in BC amended soils.

Acknowledgements. This work was supported by Science and Technology Major Projects of Fujian Province [2018NZ0001-1], Fujian Seedling Science and Technology Research Project, P. R. China.

\section{REFERENCES}

[1] Abiven, S., Hund, A., Martinsen, V., Cornelissen, G. (2015): Biochar amendment increases maize root surface areas and branching: a shovelomics study in Zambia. - Plant Soil 395: 45-55. https://doi.org/10.1007/s11104-015-2533-2.

[2] Alburquerque, J. A., Salazar, P., Barrón, V., Torrent, J., del Campillo, M. del C., Gallardo, A., Villar, R. (2013): Enhanced wheat yield by biochar addition under different mineral fertilization levels. - Agron. Sustain. Dev. 33: 475-484.

[3] Alexander, L. V, Zhang, X., Peterson, T. C., Caesar, J., Gleason, B., Tank, A. M. G. K., Haylock, M., Collins, D., Trewin, B., Rahimzadeh, F. (2006): Global observed changes in daily climate extremes of temperature and precipitation. - J. Geophys. Res. Atmos. 111. 
[4] Ali, S., Rizwan, M., Qayyum, M. F., Ok, Y. S., Ibrahim, M., Riaz, M., Arif, M. S., Hafeez, F., Al-Wabel, M. I., Shahzad, A. N. (2017): Biochar soil amendment on alleviation of drought and salt stress in plants: a critical review. - Environ. Sci. Pollut. Res. 24: 12700-12712. https://doi.org/10.1007/s11356-017-8904-x.

[5] Altland, J. E., Locke, J. C. (2013): Gasified rice hull biochar is a source of phosphorus and potassium for container-grown plants. - J. Environ. Hortic. 31: 138-144.

[6] Ameloot, N., Graber, E. R., Verheijen, F. G. A., De Neve, S. (2013): Interactions between biochar stability and soil organisms: review and research needs. - Eur. J. Soil Sci. 64: 379-390.

[7] Amonette, J. E., Joseph, S. (2009): Characteristics of biochar: microchemical properties. - Biochar Environ. Manag. Sci. Technol. 33.

[8] Anderegg, W. R. L., Flint, A., Huang, C., Flint, L., Berry, J. A., Davis, F. W., Sperry, J. S., Field, C. B. (2015): Tree mortality predicted from drought-induced vascular damage. - Nat. Geosci. 8: 367.

[9] Billow, C., Matson, P., Yoder, B. (1994): Seasonal biochemical-changes in coniferous forest canopies and their response to fertilization. - Tree Physiol. 14: 563-574.

[10] Brasford, M. M. (1976): A rapid and sensitive method for quantitation of microgram quantities of protein utilizing the principle of protein-dye binding. - Anal. Biochem. 72: $248-254$.

[11] Cakmak, I., Horst, W. J. (1991): Effect of aluminium on lipid peroxidation, superoxide dismutase, catalase, and peroxidase activities in root tips of soybean (Glycine max). Physiol. Plant. 83: 463-468.

[12] Chen, L., Lai, J., He, T., Rong, J., Tarin, M. W. K., Zheng, Y. (2018): Differences in photosynthesis of variegated temple bamboo leaves with various levels of variegation are related to chlorophyll biosynthesis and chloroplast development. - J. Am. Soc. Hortic. Sci. 143: 144-153.

[13] Cheng, C.-H., Lehmann, J., Engelhard, M. H. (2008): Natural oxidation of black carbon in soils: changes in molecular form and surface charge along a climosequence. Geochim. Cosmochim. Acta 72: 1598-1610.

[14] Clough, T. J., Condron, L. M. (2010): Biochar and the nitrogen cycle: introduction. - J. Environ. Qual. 39: 1218-1223.

[15] Clough, T. J., Condron, L. M., Kammann, C., Müller, C. (2013): A review of biochar and

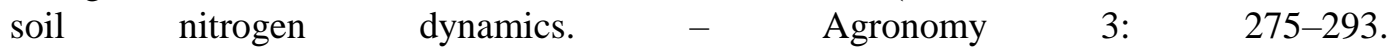
https://doi.org/10.3390/agronomy3020275.

[16] Colom, M., Prato, E. P., Giannini, R. (2003): Chlorophyll fluorescence and photosynthetic response to light in 1-year-old needles during spring and early summer in Pinus leucodermis. - Trees 17: 207-210.

[17] Danish, S., Ameer, A., Imran Qureshi, T., Manzoor, H., Shakeel, A., Ehsanullah, M. (2014): Influence of biochar on growth and photosynthetic attributes of Triticum aestivum L. under half and full irrigation. - Int. J. Biosci. https://doi.org/10.12692/ijb/5.7.101-108.

[18] Dao, T. H. H., Hölscher, D. (2017): Fujian cypress and two other threatened tree species in three conservation zones of a nature reserve in north-western Vietnam. - For. Ecosyst. 4. https://doi.org/10.1186/s40663-017-0116-9.

[19] Ding, M., Meng, K., Fan, Q., Tan, W., Liao, W., Chen, S. (2017): Development and Validation of EST-SSR Markers for Fokienia hodginsii (Cupressaceae). - Appl. Plant Sci. 5: 1600152. https://doi.org/10.3732/apps.1600152.

[20] Edenborn, S. L., Edenborn, H. M., Krynock, R. M., Haug, K. L. Z. (2015): Influence of biochar application methods on the phytostabilization of a hydrophobic soil contaminated with lead and acid tar. - J. Environ. Manage. 150: 226-234.

[21] Elmer, W. H., Pignatello, J. J. (2011): Effect of biochar amendments on mycorrhizal associations and Fusarium crown and root rot of asparagus in replant soils. - Plant Dis. 95: 960-966. 
[22] Glaser, B., Lehmann, J., Zech, W. (2002): Ameliorating physical and chemical properties of highly weathered soils in the tropics with charcoal-a review. - Biol. Fertil. Soils 35: 219-230.

[23] Graber, E. R., Harel, Y. M., Kolton, M., Cytryn, E., Silber, A., David, D. R., Tsechansky, L., Borenshtein, M., Elad, Y. (2010): Biochar impact on development and productivity of pepper and tomato grown in fertigated soilless media. - Plant Soil 337: 481-496.

[24] Hass, A., Gonzalez, J. M., Lima, I. M., Godwin, H. W., Halvorson, J. J., Boyer, D. G. (2012): Chicken manure biochar as liming and nutrient source for acid Appalachian soil. - J. Environ. Qual. 41: 1096-1106.

[25] Huang, M., Yang, L., Qin, H., Jiang, L., Zou, Y. (2014): Fertilizer nitrogen uptake by rice increased by biochar application. - Biol. Fertil. Soils 50: 997-1000.

[26] Hubbell, S. P. (2013): Tropical rain forest conservation and the twin challenges of diversity and rarity. - Ecol. Evol. 3: 3263-3274.

[27] Johnson, A. S., Ford, W. M., Hale, P. E. (1993): The effects of clearcutting on herbaceous understories are still not fully known. - Conserv. Biol. 7: 433-435.

[28] Keller, T., Schwager, H. (1977): Air pollution and ascorbic acid. - Eur. J. For. Pathol. 7: 338-350.

[29] Lehmann, J. (2007): Bio-energy in the black. - Front. Ecol. Environ. 5: 381-387.

[30] Lehmann, J., Gaunt, J., Rondon, M. (2006): Bio-char sequestration in terrestrial ecosystems-a review. Mitig. Adapt. Strateg. - Glob. Chang. 11: 403-427.

[31] Liang, B., Lehmann, J., Solomon, D., Kinyangi, J., Grossman, J., O'neill, B., Skjemstad, J. O., Thies, J., Luizao, F. J., Petersen, J. (2006): Black carbon increases cation exchange capacity in soils. - Soil Sci. Soc. Am. J. 70: 1719-1730.

[32] Lichtenthaler, H. K. (1987): Chlorophylls and carotenoids: pigments of photosynthetic biomembranes. - Methods in Enzymology 148: 350-382.

[33] Luu, N. D. T., Thomas, P. I. (2000): Conifers of Vietnam. - Foreign Languages Pub. House, Hanoi.

[34] Major, J., Rondon, M., Molina, D., Riha, S. J., Lehmann, J. (2010): Maize yield and nutrition during 4 years after biochar application to a Colombian savanna oxisol. - Plant Soil 333: 117-128.

[35] Manuel, L., Nuñez, V., Gérant, D., Maillard, P., Bréda, N. (2004): Seasonal dynamics of total soluable proteins in adult trees of Quercus petraea (Matts.) Liebl. and Fagus sylvatica L. - Rev. Mex. Cien. For. 1: 75-83.

[36] Matson, P., Johnson, L., Billow, C., Miller, J., Pu, R. (1994): Seasonal patterns and remote spectral estimation of canopy chemistry across the Oregon transect. - Ecol. Appl. 4: 280-298.

[37] McElligott, K. M. (2011): Biochar amendments to forest soils: effects on soil properties and tree growth. - A thesis presented in partial fulfillment of the requirements for the degree of master of science with a major in natural resources in the College of Graduate Studies, University of Idaho.

[38] Min, S.-K., Son, S.-W., Seo, K.-H., Kug, J.-S., An, S.-I., Choi, Y.-S., Jeong, J.-H., Kim, B.-M., Kim, J.-W., Kim, Y.-H. (2015): Changes in weather and climate extremes over Korea and possible causes: A review. - Asia-Pacific J. Atmos. Sci. 51: 103-121.

[39] Nguyen, D. Q., Phan, T. P. H., Dao, V. T. (2015): Effect of storage time and pretreatment on seed germination of the threatened coniferous species Fokienia hodginsii. - Plant Species Biol. 30: 291-296. https://doi.org/10.1111/1442-1984.12062.

[40] Osborn, T. (2004): Preparation and Implementation of a Strategy for the Management of Fokienia Hodginsii in Vietnam by 2008. - FFI, Hanoi.

[41] Pansu, M., Gautheyrou, J. (2007): Handbook of Soil Analysis: Mineralogical, Organic and Inorganic Methods. - Springer Science \& Business Media, Berlin.

[42] Pant, P. P., Tripathi, A. K., Dwivedi, V. (2011): Effect of heavy metals on some biochemical parameters of sal (Shorea robusta) seedling at nursery level, Doon Valley, India. - J. Agric. Sci. 2: 45-51. 
[43] Richardson, A. D., Berlyn, G. P., Gregoire, T. G. (2001): Spectral reflectance of Picea rubens (Pinaceae) and Abies balsamea (Pinaceae) needles along an elevational gradient, Mt. Moosilauke, New Hampshire, USA. - Am. J. Bot. 88: 667-676.

[44] Rondon, M. A., Lehmann, J., Ramírez, J., Hurtado, M. (2007): Biological nitrogen fixation by common beans (Phaseolus vulgaris L.) increases with bio-char additions. Biol. Fertil. Soils 43: 699-708.

[45] Saarnio, S., Heimonen, K., Kettunen, R. (2013): Biochar addition indirectly affects $\mathrm{N}_{2} \mathrm{O}$ emissions via soil moisture and plant N uptake. - Soil Biol. Biochem. 58: 99-106.

[46] Sarfraz, R., Shakoor, A., Abdullah, M., Arooj, A., Hussain, A., Xing, S. (2017): Impact of integrated application of biochar and nitrogen fertilizers on maize growth and nitrogen recovery in alkaline calcareous soil. - Soil Sci. Plant Nutr. 63: 488-498. https://doi.org/10.1080/00380768.2017.1376225.

[47] Shao, H.-B., Chu, L.-Y., Jaleel, C. A., Zhao, C.-X. (2008): Water-deficit stress-induced anatomical changes in higher plants. - C. R. Biol. 331: 215-225.

[48] Siminovitch, D. (1981): Common and disparate elements in the processes of adaptation of herbaceous and woody plants to freezing. A perspective. - Cryobiology 18: 166-185. https://doi.org/10.1016/0011-2240(81)90088-2.

[49] Sodhi, N. S., Koh, L. P., Brook, B. W., Ng, P. K. L. (2004): Southeast Asian biodiversity: an impending disaster. - Trends Ecol. Evol. 19: 654-660.

[50] Tarin, M. W., Nizami, S. M., Jundong, R., Lingyan, C., You, H., Farooq, T. H., Gilani, M. M., Ifthikar, J., Tayyab, M., Zheng, Y. (2017): Range vegetation analysis of Kherimurat Scrub Forest, Pakistan. - Int. J. Dev. Sustain. 66: 2186-8662.

[51] Tayyab, M., Islam, W., Khalil, F., Ziqin, P., Caifang, Z., Arafat, Y., Hui, L., Rizwan, M., Ahmad, K., Waheed, S., Tarin, M. W. K., Hua, Z. (2018): Biochar: an efficient way to manage low water availability in plants. - Appl. Ecol. Environ. Res. 16: 2565-2583. https://doi.org/10.15666/aeer/1603_25652583.

[52] Thomas, P., Yang, Y. (2013): Fokienia hodginsii. The IUCN Red List of Threatened Species 2013: $\quad$ e.T32351A2815809. http://dx.doi.org/10.2305/IUCN.UK.20131.RLTS.T32351A2815809.en

[53] Thomas, S. C., Gale, N. (2015): Biochar and forest restoration: a review and metaanalysis of tree growth responses. - New For. 46: 931-946.

[54] Thornley, J. H. M. (1976): Mathematical Models in Plant Physiology. - Academic Press, London.

[55] Uzoma, K. C., Inoue, M., Andry, H., Fujimaki, H., Zahoor, A., Nishihara, E. (2011): Effect of cow manure biochar on maize productivity under sandy soil condition. - Soil Use Manag. 27: 205-212.

[56] Vassilev, N., Martos, E., Mendes, G., Martos, V., Vassileva, M. (2013): Biochar of animal origin: a sustainable solution to the global problem of high-grade rock phosphate scarcity? -- J. Sci. Food Agric. 93: 1799-1804.

[57] Vieira, G. (1996): Gap dynamics in managed Amazonian forest: structural and ecophysiological aspects. - Doctoral Thesis, University of Oxford.

[58] Wang, Y., Pan, F., Wang, G., Zhang, G., Wang, Y., Chen, X., Mao, Z. (2014): Effects of biochar on photosynthesis and antioxidative system of Malus hupehensis Rehd. seedlings under replant conditions. - Sci. Hortic. 175: 9-15. https://doi.org/10.1016/j.scienta.2014.05.029.

[59] Wardle, D. A., Zackrisson, O., Nilsson, M.-C. (1998): The charcoal effect in Boreal forests: mechanisms and ecological consequences. - Oecologia 115: 419-426.

[60] Watanabe, M., Kinose, Y., Izuta, T. (2018): Photosynthesis of three evergreen broadleaved tree species, Castanopsis sieboldii, Quercus glauca, and Q. Myrsinaefolia, under elevated ozone. - IForest 11: 360-366. https://doi.org/10.3832/ifor2493-011.

[61] Weng, J. H., Liao, T. S., Sun, K. H., Chung, J. C., Lin, C. P., Chu, C. H. (2005): Seasonal variations in photosynthesis of Picea morrisonicola growing in the subalpine region of 
$\begin{array}{llllll}\text { subtropical Taiwan. } & - & \text { Tree } & \text { Physiol. } & \text { 25: }\end{array}$ https://doi.org/10.1093/treephys/25.8.973.

[62] Xu, C. Y., Hosseini-Bai, S., Hao, Y., Rachaputi, R. C. N., Wang, H., Xu, Z., Wallace, H. (2015): Effect of biochar amendment on yield and photosynthesis of peanut on two types of soils. - - Environ. Sci. Pollut. Res. 22: 6112-6125. https://doi.org/10.1007/s11356014-3820-9.

[63] Ye, Z., Suggett, D. J., Robakowski, P., Kang, H. (2013): A mechanistic model for the photosynthesis-light response based on the photosynthetic electron transport of photosystem II in C3 and C4 species. - New Phytol. 199: 110-120.

[64] Ye, Z.-P. (2007): A new model for relationship between irradiance and the rate of photosynthesis in Oryza sativa. - Photosynthetica 45: 637-640.

[65] Younis, U., Athar, M., Malik, S. A., Raza Shah, M., Mahmood, S. (2015): Biochar impact on physiological and biochemical attributes of spinach Spinacia oleracea (L.) in nickel contaminated soil. - Glob. J. Environ. Sci. Manag. 1: 245-254.

[66] Yuanyuan, M., Yali, Z., Jiang, L., Hongbo, S. (2010): Roles of plant soluble sugars and their responses to plant cold stress. - J. Biotechnol. 8: 2004-2010. 